\title{
Clinical characteristics and effects of GH replacement therapy in adults with childhood-onset craniopharyngioma compared with those in adults with other causes of childhood-onset hypothalamic-pituitary dysfunction
}

Kevin C J Yuen, Maria Koltowska-Häggström ${ }^{1}$, David M Cook* ${ }^{*}$ Janet L Fox ${ }^{2}$, Peter J Jönsson ${ }^{1}$, Mitchell E Geffner ${ }^{3}$ and Roger Abs ${ }^{4}$

Division of Endocrinology, Diabetes and Clinical Nutrition, Department of Medicine, Oregon Health and Science University, 3181 SW Sam Jackson Park Road, Mailcode: L607, Portland, Oregon 97239-3098, USA, ${ }^{1}$ Pfizer Endocrine Care, Pfizer, Inc., SE-190 91 Sollentuna, Sweden, ${ }^{2}$ Pfizer Endocrine Care, Pfizer, Inc., New York, New York 10017, USA, ${ }^{3}$ The Saban Research Institute, Children's Hospital Los Angeles, Los Angeles, California 90027, USA and ${ }^{4}$ Antwerp Centre for Endocrinology, Antwerp B-2600, Belgium

(Correspondence should be addressed to K C J Yuen; Email: yuenk@ohsu.edu)

*(This paper is dedicated to D M Cook who sadly passed away after the completion and prior to the acceptance of the manuscript)

\begin{abstract}
Objective: Adults with childhood-onset (CO) craniopharyngioma (COCP) have poor quality of life (QoL) and clinical outcomes, but few studies have compared these patients with adults with other causes of CO hypothalamic-pituitary dysfunction. In this study, we compared baseline clinical characteristics and patient-reported outcomes before starting GH replacement therapy in adults with GH deficiency (GHD) due to COCP with those of adults either with CO idiopathic/congenital hypopituitarism (COH) or with $\mathrm{CO}$ extrasellar (COE) tumours, and evaluated the 1- and 5-year effects of $\mathrm{GH}$ replacement therapy. Subjects and methods: Retrospective analysis of the data recorded in KIMS (Pfizer International Metabolic Database) was carried out. Patients with $\mathrm{COCP}, \mathrm{COH}$ and $\mathrm{COE}$ tumours were evaluated at baseline, and after 1 and 5 years of therapy.

Results: Compared with $\mathrm{COH}$ and $\mathrm{COE}$ patients, more COCP patients underwent surgery, had greater abnormalities of body composition and higher prevalence of pituitary hormone deficits (all $P<0.001$ ), but comparable fasting glucose, $\mathrm{HbA1c}$, total cholesterol and LDL-cholesterol levels, marital status, parenthood, living arrangements, education, employment and annual sick-leave days. After 1 and 5 years of GH replacement therapy, similar changes were evident with regard to body composition, fasting glucose and $\mathrm{HbA1c}$ levels, QoL, and the level of and satisfaction with physical activity across the three groups. Conclusions: Adults with untreated COCP with GHD at baseline demonstrated more co-morbidities including greater abnormalities of body composition, pituitary hormone deficits and visual field defects. Overall, adults with $\mathrm{COCP}, \mathrm{COH}$ and $\mathrm{COE}$ tumours responded comparably to short- and long-term GH replacement therapy, suggesting that patients with GHD due to $\mathrm{COCP}$ benefited from $\mathrm{GH}$ replacement therapy to a similar degree as those with other causes of $\mathrm{CO}$ hypothalamic-pituitary dysfunction did.
\end{abstract}

European Journal of Endocrinology 169 511-519

\section{Introduction}

Craniopharyngioma is the most common tumour to affect the hypothalamic-pituitary region in children, accounting for $5.6-13 \%$ of all paediatric intracranial tumours (1). Although histologically benign, most patients with craniopharyngiomas $(85-90 \%)$ have significant pituitary hormone deficits $(2,3)$ with growth hormone (GH) deficiency (GHD) being the most common (54-100\%) (4), and have decreased quality of life (QoL) with significant psychosocial and neurocognitive impairment (3). Previous studies have reported that patients with craniopharyngiomas not only have three- to fivefold higher morbidity and mortality rates compared with the general population $(3,5)$, but also have higher morbidity and mortality rates compared with patients with other causes of hypopituitarism, namely those with non-functioning pituitary adenomas (6).

Surgical resection is the primary treatment modality for patients with childhood-onset (CO) craniopharyngioma (COCP), and radiotherapy is usually considered when surgical resection is incomplete or not feasible. Due to the propensity for local recurrence of the tumour, more extensive and/or multiple surgeries and/or radiotherapy is frequently advocated, which 
often results in hypothalamic-pituitary dysfunction in these patients. Hypothalamic damage has been implicated as the main risk factor for obesity in patients with COCP (7), and the increased cardiovascular risk and poor QoL have been reported to be related to both obesity and $\operatorname{GHD}(3,8)$ in these patients. In addition, GHD due to COCP has been reported to increase the risk of metabolic syndrome (9).

Few studies, however, have compared the clinical characteristics and patient-reported outcomes (PROs) of adults with COCP with those of patients with other causes of $\mathrm{CO}$ hypothalamic-pituitary dysfunction. Furthermore, the impact of hypothalamic damage on clinical characteristics and PROs is difficult to differentiate from that of GHD per se in COCP patients in adulthood. While the benefits of GH replacement therapy in children and adults with GHD are well recognised, adults with GHD due to craniopharyngioma in these studies have been analysed together with patients with other aetiologies of intracranial tumours (10), making it difficult to ascertain whether there were any differences in tumoural behaviour per se and/or in their response to GH replacement therapy.

Therefore, the first aim of this study was to examine the effects of surgery and/or radiotherapy and GHD per se on the clinical characteristics and PROs of COCP patients. To delineate the effects of surgery and/or radiotherapy, we compared COCP patients with $\mathrm{CO}$ idiopathic/congenital hypopituitarism $(\mathrm{COH})$ patients (surrogate group for no hypothalamic-pituitary surgery and no radiotherapy), whereas to determine the effects of GHD per se, we compared COCP patients with those with $\mathrm{CO}$ extrasellar (COE) tumours who had intracranial tumours distant from the hypothalamic-pituitary region (surrogate group for no hypothalamic-pituitary surgery, but with extrasellar surgery and radiotherapyinduced GHD). The second aim of this study was to evaluate the short- and long-term effects of $\mathrm{GH}$ replacement therapy in these three groups of patients.

\section{Subjects and methods}

\section{Patients}

Data of patients for whom 1-year $(n=805)$ and 5-year $(n=390)$ follow-up was available were extracted from KIMS (Pfizer International Metabolic Database), the largest pharmacoepidemiological surveillance study on GH replacement therapy in adults with GHD of various aetiologies (11). The patients enrolled between 1994 and 2011 were mainly from Europe $(n=767,95.3 \%)$. The study cohort comprised of patients with COCP and two groups of age- and sex-matched patients with $\mathrm{COH}$ and COE tumours. Diagnostic procedures were carried out according to the medical standards at each centre, and information about primary diagnosis was dependent upon the reporting of the investigators at these centres. While $16 \%$ of the patients were never treated with $\mathrm{GH}, 84 \%$ of the patients were previously treated with $\mathrm{GH}$, but had discontinued GH therapy at least 6 months prior to the baseline visit, defined as time of their enrolment into KIMS. All patients had GHD confirmed by GH stimulation testing (in $\mathrm{COH}$ patients, the GH stimulation test was carried out at least 4 weeks following the discontinuation of GH therapy after final height was determined) or had at least three pituitary hormone deficits and a low serum insulin-like growth factor 1 (IGF1) SDS of $<-2$, in accordance with current consensus guidelines $(12,13)$. The data collection into KIMS was approved by the Institutional Review Boards/Ethical Committees as required by local regulations in each participating country. Written informed consent was obtained from all the patients before any data were entered into KIMS.

\section{Methods}

In this study of $\mathrm{COCP}, \mathrm{COH}$ and $\mathrm{COE}$ patients, two separate analyses were carried out: i) cross-sectional analysis comparing clinical characteristics, anthropometry, laboratory parameters, QoL and PROs such as personal and societal functioning and ii) longitudinal analysis of changes in anthropometry, metabolic profile and PROs after 1 and 5 years of GH replacement therapy.

From 1994 to 1997, measurements of serum IGF1 levels were carried out at Kabi Pharmacia (Stockholm, Sweden) and thereafter at Sahlgrenska University Hospital (Gothenburg, Sweden), using the following assay methods: until November 2002, RIA after acid/ethanol precipitation of IGF-binding proteins (Nichols Institute Diagnostic, San Clemente, CA, USA); until September 2006, chemiluminescence immunoassay (Nichols Advantage System); and after September 2006, Immulite 2500 (DPC Siemens, Erlangen, Germany) (14). Intra-assay, inter-assay and total coefficients of variation were $<9 \%$ in the concentration range of $125-1046 \mu \mathrm{g} / \mathrm{l}$. The assay detection limit was $13.5 \mu \mathrm{g} / \mathrm{l}$. To make comparisons between IGF 1 measurements valid and meaningful, age- and genderspecific reference ranges, as well as statistical formulae for each of the methods, were used to calculate an IGF1 SDS for each patient $(15,16)$. Lipid profiles were measured centrally as described previously $(17,18)$, while plasma glucose and haemoglobin A1c (HbA1c) levels were analysed locally at each participating centre.

QoL was assessed using the QoL-assessment of GHD in adults (QoL-AGHDA), with high scores (maximum of 25) denoting poorer QoL (19). Other PROs such as information about personal situation, social functioning, annual sick-leave days and healthcare utilisation were self-reported in the KIMS Patient Life Situation Forms (KIMS PLSF) (20). The level of and satisfaction with physical activity were measured using visual analogue scales, and satisfaction with GH treatment was assessed using a five-point Likert scale. The GH dose 
was titrated based on clinical response, occurrence of side effects and serum IGF1 levels to the upper half of the age-dependent laboratory reference range at the discretion of the treating clinician. The GH dose was analysed as the dose reported to KIMS at baseline and after 1 and 5 years of treatment.

\section{Statistical analyses}

Statistical analyses were carried out using the Statistical Analysis System (SAS Institute, Inc., Cary, NC, USA). Baseline parameters between COCP vs $\mathrm{COH}$ patients and COCP vs COE patients were compared using unpaired $t$-tests for normally distributed data or using the Wilcoxon rank-sum test for non-normally distributed data. Treatment effects within groups after 1 and 5 years of GH treatment compared with baseline were analysed using paired $t$-tests and those between groups using unpaired $t$-tests for normally distributed data or using the Wilcoxon rank-sum test for non-normally distributed data. Comparisons of proportions were analysed using Fisher's exact test or the $\chi^{2}$ test as appropriate. Multiple comparisons were made for the three groups, and statistical significance was accepted at $P<0.01$ to correct for these comparisons.

\section{Results}

\section{Cross-sectional analysis}

Clinical characteristics and medical history of patients at enrolment into KIMS The three groups of patients were well matched for age and gender. Primary diagnoses for the $\mathrm{COH}$ and $\mathrm{COE}$ groups are given in Table 1. The estimated duration of GHD was comparable between the COCP and COE groups, while the $\mathrm{COH}$ group had the longest duration.

Compared with COE patients, more COCP patients were treated by surgery alone, but fewer were treated by combined surgery and radiotherapy or radiotherapy or chemotherapy alone. Patients with COCP had more pituitary hormone deficits compared with $\mathrm{COH}$ and $\mathrm{COE}$ patients, with the most striking difference being observed for diabetes insipidus.

Table 1 Clinical characteristics and medical history of patients at enrolment into KIMS. Data for age when enrolled into KIMS and duration of GHD are presented as mean (S.D.).

\begin{tabular}{|c|c|c|c|}
\hline & $\begin{array}{c}\text { COCP } \\
(n=260)\end{array}$ & $\underset{(n=433)}{\mathbf{C O H}}$ & $\underset{(n=112)}{\operatorname{COE}}$ \\
\hline Age when enrolled into KIMS (years) & $27.1(9.1)$ & $29.0(9.9)$ & $23.1(6.0)$ \\
\hline \multicolumn{4}{|l|}{ Gender } \\
\hline Males $(n(\%))$ & $152(58.5)$ & $262(60.5)$ & $64(57.1)$ \\
\hline Females $(n(\%))$ & $108(41.5)$ & $171(39.5)$ & $48(42.9)$ \\
\hline \multirow[t]{5}{*}{ Primary diagnosis $(n)$} & $\operatorname{COCP}(260)$ & Idiopathic GHD (362) & Astrocytoma (29) \\
\hline & & Congenital GHD (71) & $\begin{array}{c}\text { Ependymoma (2) } \\
\text { Glioma (6) }\end{array}$ \\
\hline & & & Medulloblastoma (56) \\
\hline & & & Nasopharyngeal tumours (4) \\
\hline & & & Other tumours (15) \\
\hline Duration of GHD (years) & $8.9(8.3)$ & $14.3(10.2)^{\star}$ & $7.2(7.0)$ \\
\hline \multicolumn{4}{|l|}{ Previous therapy $(n(\%))$} \\
\hline Surgery only & $158(60.8)$ & $0(0)$ & $15(13.4)^{\star}$ \\
\hline Surgery and radiotherapy & $94(36.2)$ & $0(0)$ & $72(64.3)^{\star}$ \\
\hline Radiotherapy only & $8(3.1)$ & $0(0)$ & $25(22.3)^{\star}$ \\
\hline No surgery or radiotherapy & $0(0)$ & $433(100)$ & $0(0)$ \\
\hline Chemotherapy & $1(0.4)$ & $0(0)$ & $44(39.3)^{\star}$ \\
\hline \multicolumn{4}{|l|}{ Hormone deficiencies $(n(\%))$} \\
\hline Hypoadrenalism & $238(92.3)$ & $258(59.7)^{\star}$ & $30(27.0)^{*}$ \\
\hline Hypothyroidism & $255(98.1)$ & $353(81.5)^{\star}$ & $62(55.4)^{\star}$ \\
\hline Hypogonadism & $248(95.8)$ & $371(85.7)^{\star}$ & $40(36.4)^{*}$ \\
\hline Diabetes insipidus & $193(75.4)$ & $28(6.5)^{\star}$ & $11(10.0)^{\star}$ \\
\hline \multicolumn{4}{|l|}{ Medical history $(n(\%))$} \\
\hline Hypertension & $7(2.7)$ & $12(2.8)$ & $2(1.8)$ \\
\hline Claudication & $1(0.4)$ & $1(0.2)$ & $0(0)$ \\
\hline Coronary artery disease & $0(0)$ & $4(0.9)$ & $0(0)$ \\
\hline Stroke & $1(0.4)$ & $1(0.2)$ & $0(0)$ \\
\hline Diabetes mellitus & $8(3.3)$ & $3(0.8)$ & $2(1.9)$ \\
\hline Epilepsy & $22(11.0)$ & $9(3.0)^{\star}$ & $16(15.4)$ \\
\hline Secondary neoplasm/s & $3(1.2)$ & $5(1.2)$ & $3(2.7)$ \\
\hline Fractures & $37(14.6)$ & $70(16.6)$ & 17 (16.2) \\
\hline Visual field defects & $108(56.6)$ & $0(0)^{*}$ & $25(32.9)^{*}$ \\
\hline Ophthalmoplegia & $20(11.7)$ & $2(1.4)^{\star}$ & $12(17.5)$ \\
\hline
\end{tabular}

${ }^{*} P<0.001$ vs COCP patients. 
Table 2 Baseline anthropometric parameters, starting GH doses, biochemical parameters and QoL-AGHDA scores. Data are presented as mean (S.D.).

\begin{tabular}{|c|c|c|c|}
\hline & $\begin{array}{c}\text { COCP } \\
(n=260)\end{array}$ & $\underset{(n=433)}{\mathrm{COH}}$ & $\underset{(n=112)}{\operatorname{COE}}$ \\
\hline \multicolumn{4}{|l|}{ Height $(\mathrm{cm})$} \\
\hline Males & $174.8(9.0)$ & $167.4(9.6)^{\star}$ & $167.5(11.8)^{\star}$ \\
\hline Females & $161.0(6.9)$ & $155.3(10.6)^{\star}$ & $155.4(8.8)^{\star}$ \\
\hline \multicolumn{4}{|l|}{ Weight $(\mathrm{kg})$} \\
\hline Males & $90.9(25.9)$ & $69.1(15.0)^{\star}$ & $71.6(21.6)^{\star}$ \\
\hline Females & $79.0(23.4)$ & $60.0(15.4)^{\star}$ & $64.1(15.8)^{\star}$ \\
\hline \multicolumn{4}{|l|}{$\operatorname{BMI}\left(\mathrm{kg} / \mathrm{m}^{2}\right)$} \\
\hline Males & $29.5(7.2)$ & $24.6(4.7)^{\star}$ & $25.2(5.5)^{\star}$ \\
\hline Females & $30.4(8.9)$ & $249(66)^{*}$ & $26.7(6.7)^{\dagger}$ \\
\hline \multicolumn{4}{|c|}{ Waist circumference $(\mathrm{cm})$} \\
\hline Males & $101.0(17.0)$ & $86.8(12.4)^{\star}$ & $89.9(15.7)^{\star}$ \\
\hline Females & $97.1(17.8)$ & $3.6)^{\star}$ & $85.2(13.3)^{*}$ \\
\hline \multicolumn{4}{|l|}{ BIA fat mass $(\mathrm{kg})$} \\
\hline Males & $33.6(18.7)$ & $18.5(9.5)^{\star}$ & $22.9(16.7)^{\dagger}$ \\
\hline Females & 31.3( & $20.7(7.8)^{\dagger}$ & $27.0(11.9)$ \\
\hline \multicolumn{4}{|c|}{ BIA lean body mass $(\mathrm{kg})$} \\
\hline Males & $63.8(13.6)$ & $53.0(11.0)^{\star}$ & $51.2(12.3)^{\star}$ \\
\hline Females & $45.3(9.3)$ & $37.5(6.9)^{\star}$ & $39.5(9.2)$ \\
\hline $\begin{array}{l}\text { Starting GH dose } \\
\text { (mg/day) }\end{array}$ & $0.3(0.3)$ & $0.3(0.2)$ & $0.3(0.2)$ \\
\hline IGF1 SDS & $-4.2(2.2)$ & $-4.7(2.1)$ & $-2.3(1.2)^{\star}$ \\
\hline $\begin{array}{l}\text { Total cholesterol } \\
(\mathrm{mmol} / \mathrm{l})\end{array}$ & $5.7(1.5)$ & $5.5(1.3)$ & $5.4(1.2)$ \\
\hline $\begin{array}{l}\text { LDL-cholesterol } \\
(\mathrm{mmol} / \mathrm{l})\end{array}$ & $3.5(1.2)$ & $3.5(1.2)$ & $3.3(1.1)$ \\
\hline $\begin{array}{l}\text { HDL-cholesterol } \\
(\mathrm{mmol} / \mathrm{l})\end{array}$ & $1.2(0.4)$ & $1.3(0.4)^{\dagger}$ & $1.2(0.5)$ \\
\hline $\begin{array}{l}\text { Triglycerides } \\
(\mathrm{mmol} / \mathrm{l})\end{array}$ & $2.7(2.5)$ & $1.7(1.5)^{\star}$ & $2.0(1.3)$ \\
\hline $\begin{array}{l}\text { Fasting glucose } \\
\qquad(\mathrm{mmol} / \mathrm{l})\end{array}$ & $4.6(1.3)$ & $4.7(0.7)$ & $4.7(1.1)$ \\
\hline $\mathrm{HbA1c}(\%)$ & $5.1(1.0)$ & $5.2(0.9)$ & $5.2(0.7)$ \\
\hline \multicolumn{4}{|c|}{ QoL-AGHDA score (points) } \\
\hline Males & $9.7(6.6)$ & $8.6(7.0)$ & $11.5(6.9)$ \\
\hline Females & $11.3(6.7)$ & $8.8(6.6)$ & $14.2(6.1)$ \\
\hline
\end{tabular}

BIA, bioelectrical impedance analysis. ${ }^{\star} P<0.001$ and ${ }^{\dagger} P<0.01$ vs COCP patients.

Comparable numbers of COCP, $\mathrm{COH}$ and COE patients had hypertension, claudication, coronary artery disease, stroke, diabetes mellitus, secondary neoplasm/s and fractures. Compared with $\mathrm{COH}$ patients, a larger proportion of COCP patients had epilepsy, visual field defects and ophthalmoplegia, and higher numbers of $\mathrm{COCP}$ patients reported visual field defects compared with COE patients.

\section{Baseline anthropometric and biochemical parameters, QoL, and personal and societal functioning Patients with COCP of both genders were} taller, weighed more, and had greater BMI and waist circumference compared with $\mathrm{COH}$ and $\mathrm{COE}$ patients (Tables 2 and 3). The proportion of fat mass was highest (COCP $36.7 \%$, $\mathrm{COH} 28.8 \%$ and $\mathrm{COE} 35.2 \%$ ) and lean body mass was lowest (COCP $63.3 \%, \mathrm{COH} 71.2 \%$ and COE $64.8 \%$ ) in COCP patients when compared with those in $\mathrm{COH}$ and $\mathrm{COE}$ patients. Fat mass and lean body mass were higher in male and female COCP patients compared with those in male and female $\mathrm{COH}$ patients and were higher in male COCP patients compared with those in male COE patients (between-group gender comparisons). By contrast, when the anthropometric parameters were analysed according to gender within groups (within-group gender comparisons), there were no differences between males and females within all the three groups.

At baseline, starting GH doses were similar for all the three groups, while IGF1 SDS of COCP and $\mathrm{COH}$ patients were lower compared with that of the COE group. With regard to lipid profiles, there were no differences in all the three groups for total cholesterol and LDLcholesterol levels and no differences in HDL-cholesterol and triglyceride levels between COCP and COE patients, but COCP patients had lower HDL-cholesterol and higher triglyceride levels compared with $\mathrm{COH}$ patients. By contrast, there were no differences in fasting glucose and $\mathrm{HbA} 1 \mathrm{c}$ levels and QoL across all the three groups.

In addition, there were no differences in marital status, parenthood, living arrangements, education,

Table 3 Baseline personal and societal functioning (KIMS PLSF scores). Data are presented as mean (S.D.), except for data for annual sick-leave days and healthcare utilisation, which are presented as mean (10th-90th percentiles).

\begin{tabular}{|c|c|c|c|}
\hline & $\begin{array}{c}\text { COCP } \\
(n=260)\end{array}$ & $\begin{array}{c}\text { COH } \\
(n=433)\end{array}$ & $\begin{array}{c}\text { COE } \\
(n=112)\end{array}$ \\
\hline \multicolumn{4}{|l|}{ Marital status $^{\mathrm{a}}(n(\%))$} \\
\hline Unmarried & $134(80.2)$ & $202(75.7)$ & $67(93.1)$ \\
\hline Married/cohabiting & 27 (16.2) & 60 (22.5) & $5(6.9)$ \\
\hline Widow/er & $1(0.6)$ & $0(0)$ & $0(0)$ \\
\hline Divorced/separated & $5(3.0)$ & $5(1.9)$ & $0(0)$ \\
\hline Parenthood $^{\mathrm{a}}(n(\%))$ & $4(5.6)$ & $10(11.1)$ & $2(4.9)$ \\
\hline \multicolumn{4}{|c|}{ Living arrangements ${ }^{\mathrm{a}}(n(\%))$} \\
\hline Alone & $34(20.7)$ & $48(18.3)$ & $8(10.7)$ \\
\hline Spouse/partner & $22(13.4)$ & $59(22.5)$ & $6(8.0)$ \\
\hline Parents & $98(59.8)$ & $142(54.2)$ & 52 (69.3) \\
\hline Other & $10(6.1)$ & $13(5.0)$ & $9(12.0)$ \\
\hline $\begin{array}{l}\text { Requiring assistance } \\
\text { with daily activities }{ }^{a} \\
(n(\%))\end{array}$ & $40(25.3)$ & $34(13.2)^{\star}$ & $19(27.5)$ \\
\hline \multicolumn{4}{|l|}{ Education $^{\mathrm{a}}(n(\%))$} \\
\hline Primary education & $6(3.7)$ & $7(2.7)$ & $2(2.9)$ \\
\hline Junior school & $29(17.8)$ & $54(20.6)$ & $13(18.6)$ \\
\hline Secondary school & 73 (44.8) & 129 (49.2) & $37(52.9)$ \\
\hline Higher education & 55 (33.7) & $72(27.5)$ & $18(25.7)$ \\
\hline \multicolumn{4}{|l|}{ Employment $^{\mathrm{a}}(n(\%))$} \\
\hline Unemployed & $17(11.0)$ & $32(12.6)$ & $9(13.4)$ \\
\hline Sick/invalid benefit & 19 (12.3) & $18(7.1)$ & $11(16.4)$ \\
\hline Employed & 77 (49.7) & $142(55.7)$ & $27(39.7)$ \\
\hline Student & $39(25.2)$ & $53(20.8)$ & $18(26.9)$ \\
\hline Normal retirement & $0(0)$ & $1(0.4)$ & $0(0)$ \\
\hline Early retirement & $1(0.7)$ & $3(1.2)$ & $1(1.5)$ \\
\hline Running family home & $2(1.3)$ & $6(2.4)$ & $2(3.0)$ \\
\hline & $12.7(0-28)$ & $20.1(0-28)$ \\
\hline $\begin{array}{l}\text { Healthcare utilisation } \\
\text { Annual days in } \\
\text { hospital }\end{array}$ & $3.5(0-10)$ & $2.9(0-4)^{\star}$ & $3.8(0-8)$ \\
\hline Annual visits to doctor & $6.9(0-14)$ & $4.8(0-10)$ & $3.5(0-10)$ \\
\hline
\end{tabular}

${ }^{*} P<0.01$ vs COCP patients.

anformation not available for some patients. 
employment and annual sick-leave days among the three groups. However, a higher proportion of COCP patients required assistance with daily activities and a greater number of annual hospital admission days compared with $\mathrm{COH}$ patients.

\section{Longitudinal analysis after 1 and 5 years of GH replacement therapy}

General After 1 and 5 years of therapy, data were available for 805 and 390 patients respectively (Table 4). Despite comparable doses of GH after 1 year in all the three groups, lower IGF1 SDS were observed in COCP patients compared with COE patients, but after 5 years of therapy, higher $\mathrm{GH}$ doses were required in COCP patients compared with COE patients to achieve comparable IGF1 SDS in all the three groups (Fig. 1).

Changes in anthropometric and biochemical parameters, QoL, and personal and societal functioning Within-group analysis. After 1 year of therapy, weight and BMI increased in female COCP and male $\mathrm{COH}$ patients, whereas waist circumference and fat mass remained unchanged in both genders in all the three groups (Table 4). After 5 years of therapy, weight and BMI increased in both male and female COCP patients and in male $\mathrm{COH}$ and $\mathrm{COE}$ patients, and weight increased in female $\mathrm{COH}$ patients. By contrast, waist circumference and fat mass remained unchanged in both genders in all the three groups after 1 and 5 years of therapy. Lean body mass increased in male COCP and $\mathrm{COH}$ patients and in female COE patients after 1 year of therapy and in female COCP patients after 5 years of therapy.

After 1 year of therapy, GH doses and IGF1 SDS increased in all the three groups. Total cholesterol levels decreased in $\mathrm{COCP}$ and $\mathrm{COH}$ patients and LDLcholesterol levels decreased in COCP patients, whereas HDL-cholesterol and triglyceride levels remained unchanged in all the three groups. Fasting glucose levels increased in $\mathrm{COCP}$ and $\mathrm{COH}$ patients and $\mathrm{HbA1c}$ levels decreased significantly in COCP patients, whereas QoL and the level of and satisfaction with physical activity improved in all the three groups. After 5 years of therapy, GH doses and IGF1 SDS increased in all the

Table 4 Changes in anthropometric and biochemical parameters, QoL-AGHDA scores, and personal and societal functioning (KIMS PLSF scores) after 1 and 5 years of GH replacement therapy. Data are presented as mean (s.D.). A greater reduction in QoL-AGHDA scores indicates greater improvement in QoL. For the level of and satisfaction with physical activity, scores were measured using visual analogue scales, where 0 indicates the lowest level of satisfaction and 100 indicates the highest level. Satisfaction with GH treatment was assessed using a five-point Likert scale ranging from much worse to much improvement.

\begin{tabular}{|c|c|c|c|c|c|c|}
\hline & \multicolumn{3}{|c|}{ After 1 year } & \multicolumn{3}{|c|}{ After 5 years } \\
\hline & $\operatorname{COCP}(n=260)$ & $\mathrm{COH}(n=433)$ & $\operatorname{COE}(n=112)$ & $\operatorname{COCP}(n=127)$ & $\mathrm{COH}(n=211)$ & $\operatorname{COE}(n=52)$ \\
\hline \multicolumn{7}{|l|}{$\Delta$ Weight $(\mathrm{kg})$} \\
\hline Males & $1.3(5.3)$ & $1.9(4.2)^{\star}$ & $1.2(3.7)$ & $6.0(13.9)^{\star}$ & $5.4(7.7)^{\star}$ & $3.9(5.0)^{b}$ \\
\hline Females & $2.2(4.5)^{\star}$ & $0.7(4.6)$ & $2.3(7.4)$ & $7.7(9.2)^{\star}$ & $3.3(8.8)^{\star}$ & $3.2(10.2)$ \\
\hline \multicolumn{7}{|l|}{$\Delta \mathrm{BMI}\left(\mathrm{kg} / \mathrm{m}^{2}\right)$} \\
\hline Males & $0.3(1.7)$ & $0.6(1.4)^{\star}$ & $0.3(1.4)$ & $1.4(3.8)^{\star}$ & $1.7(2.7)^{\dagger}$ & $1.2(1.5)^{\dagger}$ \\
\hline Females & $0.6(1.6)^{\dagger}$ & $0.3(2.2)$ & $0.8(2.8)$ & $2.3(3.1)^{\star}$ & $1.1(3.7)$ & $0.8(5.1)$ \\
\hline \multicolumn{7}{|l|}{$\Delta$ Waist circumference $(\mathrm{cm})$} \\
\hline Males & $-1.3(6.2)$ & $0.8(6.3)$ & $-0.7(4.3)$ & $4.2(10.2)$ & $2.0(8.6)$ & $2.6(6.1)$ \\
\hline Females & $-0.7(6.5)$ & $-1.6(6.1)$ & $1.3(7.4)$ & $3.2(8.6)$ & $1.1(7.5)$ & $2.6(10.8)$ \\
\hline \multicolumn{7}{|l|}{$\Delta$ Fat mass $(\mathrm{kg})$} \\
\hline Males & $-0.8(4.8)$ & $-0.6(6.2)$ & $-2.9(4.6)$ & $3.7(14.5)$ & $-1.6(5.6)$ & $-1.8(2.1)$ \\
\hline Females & $0.6(2.5)$ & $-1.4(3.4)$ & $-0.2(2.9)$ & $-0.3(3.6)$ & $-0.8(5.1)$ & $4.8(2.6)$ \\
\hline \multicolumn{7}{|l|}{$\Delta$ Lean body mass $(\mathrm{kg})$} \\
\hline Males & $3.0(5.0)^{\dagger}$ & $3.1(4.0)^{\star}$ & $4.4(6.8)$ & $6.5(5.6)$ & $3.6(5.6)$ & $8.6(8.0)$ \\
\hline Females & $1.1(3.0)$ & $1.0(1.6)$ & $1.4(1.9)^{\dagger}$ & $4.9(2.0)^{\dagger}$ & $3.9(2.9)$ & $4.6(4.6)$ \\
\hline$\Delta \mathrm{GH}$ dose & $0.2(0.3)^{\star}$ & $0.2(0.3)^{*}$ & $0.1(0.2)^{*}$ & $0.3(0.4)^{\star}$ & $0.3(0.3)^{*}$ & $0.2(0.3)^{\star}$ \\
\hline$\Delta \mathrm{IGF} 1 \mathrm{SDS}$ & $3.2(2.1)^{\star}$ & $3.2(2.4)^{\star}$ & $2.0(1.5)^{\star}$ & $4.2(2.3)^{\star}$ & $4.00(2.3)^{\star}$ & $2.7(1.5)^{\star}$ \\
\hline$\Delta$ Total cholesterol $(\mathrm{mmol} / \mathrm{l})$ & $-0.5(0.8)^{\star}$ & $-0.3(0.9)^{\star}$ & $-0.3(0.6)$ & $-0.3(1.3)$ & $-0.5(1.1)^{\dagger}$ & $0.2(0.9)$ \\
\hline$\Delta$ LDL-cholesterol $(\mathrm{mmol} / \mathrm{l})$ & $-0.5(0.8)^{\star}$ & $-0.3(0.8)$ & $-0.2(0.6)$ & $-0.4(0.9)^{\dagger}$ & $-0.5(1.1)^{\dagger}$ & $-0.1(0.9)$ \\
\hline$\Delta \mathrm{HDL}$-cholesterol $(\mathrm{mmol} / \mathrm{l})$ & $0.1(0.3)$ & $0(0.3)$ & $0(0.2)$ & $0.1(0.3)$ & $0.1(0.3)$ & $0.2(0.1)^{\star}$ \\
\hline$\Delta$ Triglycerides $(\mathrm{mmol} / \mathrm{l})$ & $-0.8(2.3)$ & $-0.1(1.9)$ & $0(0.8)$ & $-0.6(2.4)$ & $-0.4(1.8)$ & $-0.2(1.4)$ \\
\hline$\Delta$ Fasting glucose $(\mathrm{mmol} / \mathrm{l})$ & $0.2(0.8)^{\dagger}$ & $0.2(0.9)^{\dagger}$ & $-0.1(0.9)$ & $0.3(1.1)^{\dagger}$ & $0.1(0.9)$ & $0.3(0.6)$ \\
\hline$\Delta \mathrm{HbA} 1 \mathrm{c}(\%)$ & $0.1(0.7)^{\dagger}$ & $0.1(0.5)$ & $0.3(0.8)$ & $0.3(0.9)^{\star}$ & $0.2(0.7)$ & $0.5(1.2)$ \\
\hline$\triangle$ QoL-AGHDA score (points) & $-2.9(5.3)^{\star}$ & $-3.0(4.4)^{\star}$ & $-4.8(4.8)^{\star}$ & $-3.4(4.9)^{\star}$ & $-4.2(6.3)^{\star}$ & $-3.5(5.2)^{\dagger}$ \\
\hline Level of physical activity & $7.0(25.9)^{\dagger}$ & $6.4(28.1)^{\dagger}$ & $5.2(25.1)^{\star}$ & $12.8(26.3)^{\dagger}$ & $11.6(31.3)^{\dagger}$ & $16.4(20.5)^{\dagger}$ \\
\hline $\begin{array}{l}\text { Satisfaction with physical } \\
\text { activity }\end{array}$ & $9.3(30.9)^{\dagger}$ & $7.5(35.3)^{\dagger}$ & $14.7(26.9)^{\dagger}$ & $9.9(30.5)^{\dagger}$ & $11.9(36.5)^{\dagger}$ & $15.3(27.1)^{\star}$ \\
\hline
\end{tabular}

Within-group comparisons vs baseline: ${ }^{*} P<0.001$ and ${ }^{\dagger} P<0.01$. Between-group comparisons: $\mathrm{COCP}$ vs $\mathrm{COH}$ and $\mathrm{COCP}$ vs $\mathrm{COE}$ after 1 and 5 years of GH replacement therapy; all data were not significant. 

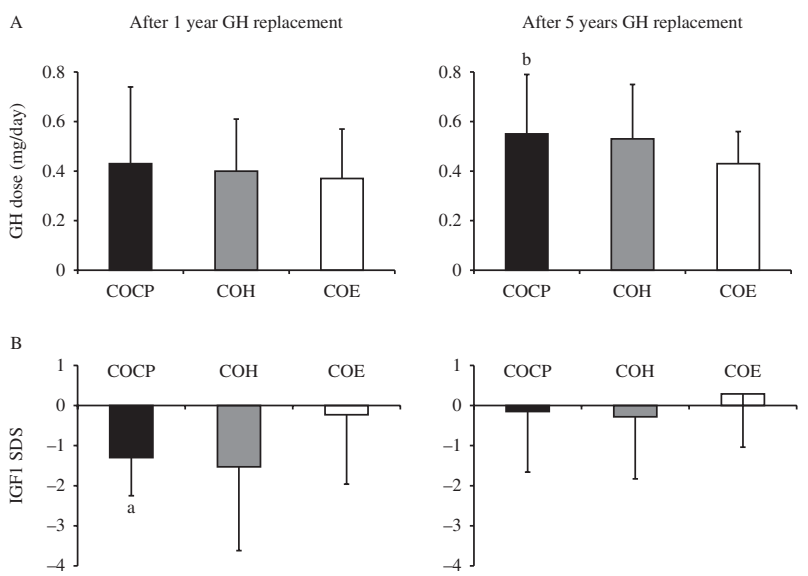

Figure 1 (A) Dose of GH used and (B) IGF1 SDS achieved after 1 and 5 years of therapy. ${ }^{\mathrm{a}} P<0.001$ and ${ }^{\mathrm{b}} P<0.01$ for $C O C P$ vs COE patients. Columns represent means and error bars represent S.D.

three groups. Total cholesterol levels decreased in $\mathrm{COH}$ patients and LDL-cholesterol levels decreased in COCP and $\mathrm{COH}$ patients, whereas HDL-cholesterol levels increased in COE patients. Fasting glucose and HbA1c levels decreased significantly in COCP patients, whereas QoL and the level of and satisfaction with physical activity improved in all the three groups.

Between-group analysis. After 1 and 5 years of therapy, there were no differences in changes in weight, BMI, waist circumference, fat mass and lean body mass among the three groups, and neither were there any differences among the three groups when analysed by gender. After 1 and 5 years of therapy, compared with $\mathrm{COH}$ and $\mathrm{COE}$ patients, COCP patients had comparable changes in IGF1 SDS, lipid profile, fasting glucose and HbA1c levels, QoL, and the level of and satisfaction with physical activity.

\section{Discussion}

In this study, we sought to compare adults with COCP with those with other causes of CO hypothalamicpituitary dysfunction with regard to clinical characteristics, QoL and PROs and evaluated the effects of short- and long-term GH replacement therapy in these subjects. We found that COCP patients were taller and had a gender-independent poorer state of body composition and a higher BMI, more pronounced pituitary hormone deficits, and more frequent rates of visual field defects compared with $\mathrm{COH}$ and $\mathrm{COE}$ patients. By contrast, total cholesterol and LDL-cholesterol, fasting glucose, and HbA1c levels, QoL, marital status, parenthood, living arrangements, education, employment and number of annual sick-leave days taken annually were comparable across the three groups. Overall, all the three groups of patients responded comparably to short- and long-term GH replacement therapy, suggesting a similar extent of treatment benefit.

In line with previous studies $(8,21)$, we found that COCP patients were taller and had higher fat mass proportions and waist circumference that fulfilled the criteria for central obesity (22) compared with $\mathrm{COH}$ and COE patients. The reason for COCP patients being taller is unclear, but the higher BMI in these patients is probably due to the greater contribution of fat rather than lean body mass. As the majority of COCP patients underwent surgery in the hypothalamic-pituitary region of the brain, these patients are prone to develop hypothalamic damage that may subsequently worsen their metabolic profiles compared with $\mathrm{COH}$ and $\mathrm{COE}$ patients and may also be more susceptible to develop postoperative epilepsy, visual field defects and ophthalmoplegia compared with $\mathrm{COH}$ patients.

Earlier studies in COCP patients have reported that pituitary hormone deficits occur in $40-87 \%$ of the cases (23). In this study, pituitary hormone deficits were more prevalent in COCP patients than in $\mathrm{COH}$ or $\mathrm{COE}$ patients, which may either be induced or be worsened by surgery and/or radiotherapy to the hypothalamicpituitary region $(21,24)$. This is in contrast to that observed in COE patients, who had lower rates of pituitary hormone deficits, where surgery and/or radiotherapy were directed to areas of the brain distant from the hypothalamic-pituitary region, suggesting that the severity of pituitary hormone deficits is more dependent on the location of the tumour and its treatment.

In this study, baseline lipid profiles were comparable between COCP and COE patients, but COCP patients had lower HDL-cholesterol and higher triglyceride levels compared with $\mathrm{COH}$ patients. Notably, QoL assessments were comparable across all the three groups, but personal situation and social functioning were worse in COCP patients compared with $\mathrm{COH}$ patients, with more COCP patients requiring assistance with daily activities and increased annual hospitalisation frequency. While adults with GHD are known to have abnormal body composition, lipid profile and QoL, based on our findings, it is possible that the greater severity of these parameters in COCP patients compared with $\mathrm{COH}$ patients is related to their hypothalamic damage exerting a greater negative influence than does GHD per se. Additionally, in COCP patients compared with $\mathrm{COH}$ patients, the higher prevalence of visual field defects and ophthalmoplegia may be caused by tumour growth or recurrence and/or its associated effects of treatment on the visual pathways, whereas epilepsy may be the result of surgery or radiotherapy.

Despite receiving higher doses of $\mathrm{GH}$, compared with COE patients, COCP patients had lower IGF1 SDS after 1 year of therapy and required higher $\mathrm{GH}$ doses at 5 years to achieve comparable IGF1 SDS. This may be due to the higher numbers of female COCP patients 
taking oral oestrogen replacement therapy, which may dampen the effects of $\mathrm{GH}$ in generating hepatic IGF1 secretion $(25,26)$.

In contrast to the effects of GH in consistently reducing fat mass when used to treat adults with GHD with other aetiologies $(27,28)$, it is noteworthy that there was no significant fat mass reduction in COCP patients. Our findings are in accordance with the data obtained by Verhelst et al. (29) in adults with adultonset craniopharyngioma demonstrating improvements in lean body mass, but not fat mass after 2 years of GH therapy, suggesting a greater tendency of COCP patients to accumulate fat over time. Overall, similar responses were observed in all the three groups with respect to the lipid profiles after 1 and 5 years of GH replacement therapy. How GH contributes to dyslipidaemia remains ill-understood, but it may involve stimulatory effects on hepatic LDL receptors with increases in LDL clearance rates (30). However, the possibility that some patients may have adopted a lowfat diet regimen or started taking lipid-lowering therapy cannot be discounted, as these data are not captured in the KIMS database.

After 1 year of $\mathrm{GH}$ replacement therapy, fasting glucose levels in $\mathrm{COCP}$ and $\mathrm{COH}$ patients and $\mathrm{HbAlc}$ levels in COCP patients decreased significantly, whereas after 5 years of GH replacement therapy, fasting glucose and $\mathrm{HbA} 1 \mathrm{c}$ levels remained impaired in COCP patients, but stabilised in $\mathrm{COH}$ and COE patients. Trivin et al. (31) reported that greater hypothalamic involvement of the tumour before surgery is associated with the worsening of insulin resistance. Other possible mechanisms include the disinhibition of vagal tone in pancreatic $\beta$-cells leading to insulin hypersecretion and obesity (32) and higher $\mathrm{GH}$ dose requirements resulting in worsening glucose tolerance (33).

Short- and long-term GH replacement therapy improved QoL and the level of and satisfaction with physical activity in all the three groups. However, when COCP patients were compared with $\mathrm{COH}$ and $\mathrm{COE}$ patients after 1 year of $\mathrm{GH}$ replacement therapy, there were no differences in changes in their level of and satisfaction with physical activity. After 5 years of GH replacement therapy, COCP patients reported changes in their level of and satisfaction with physical activity to a lesser degree compared with COE patients. Long-term effects of surgery and/or radiotherapy, as well as a higher prevalence of pituitary hormone deficits in COCP patients, could explain these observations.

There are several limitations to this study. For the cross-sectional analysis, the patients were identified based on their entry diagnosis in the database, whereas for the longitudinal analysis, we defined short-term GH effects as those resulting from treatment for 1 year and long-term GH effects arbitrarily as those resulting from treatment for 5 years to ensure that patients had received GH therapy for a reasonable duration. Furthermore, because data entered into KIMS rely upon local treatment practices and the discretion of the practising investigators, it is inevitable that there will be some selection bias in patient data entry. Finally, as KIMS is a large observational database that reflects daily clinical practice, it will be difficult to ascertain patient adherence, changes in dosing regimens and route of administration of other hormonal replacement therapies with each individual patient. While these limitations are inherent to data entry into KIMS, the major strengths of this study are that it comprises the largest series of adults with GHD due to COCP compared with those with two other relatively rare causes of $\mathrm{CO}$ hypothalamic-pituitary dysfunction and includes data recorded for more than 20 years for IGF1 levels measured within a time frame at a central laboratory utilising the same IGF1 assay methodology.

In conclusion, COCP patients demonstrated a higher prevalence of co-morbidities, most notably greater abnormalities of body composition, pituitary hormone deficits and visual field defects compared with $\mathrm{COH}$ and COE patients. These differences imply that COCP patients carry a significant excess metabolic and endocrine risk, which is greater than that carried by both $\mathrm{COH}$ and $\mathrm{COE}$ patients, and reinforce the findings of previous studies of higher morbidity and mortality rates in these patients $(4,34)$. Overall, all the three groups responded comparably to short- and long-term GH replacement therapy, suggesting that COCP patients benefit from GH replacement therapy to a similar degree as those with other aetiologies of CO hypothalamic-pituitary dysfunction did. Because of greater co-morbidity and the comparable benefits of GH replacement therapy in COCP patients compared with $\mathrm{COH}$ and $\mathrm{COE}$ patients, we recommend early confirmation of GHD and initiation of GH replacement in COCP patients.

\section{Declaration of interest}

K C J Yuen, D M Cook and R Abs were KIMS investigators and K C J Yuen and R Abs were members of the KIMS International Board. K C J Yuen has received research grants from Pfizer, Novo Nordisk, Eli Lilly and Versartis and served on the advisory boards for Pfizer, Novo Nordisk and Corcept Therapeutics. D M Cook has received lecture fees from Pfizer and research funding from Serono, Eli Lilly and Endo Pharmaceuticals and has served on the advisory board for Novo Nordisk. M Koltowska-Häggström and P J Jönsson are employed by Pfizer Health AB (Sweden). All statistical analyses were carried out by a statistician (P J Jönsson) employed by Pfizer Health AB. J L Fox is a full-time employee of Pfizer, Inc. M E Geffner has received research grants from Eli Lilly, Genentech, Novo Nordisk and Versartis, served on a data safety monitoring board and has a research contract from Ipsen and served on the advisory boards for Merck-Serono and Pfizer. M E Geffner and R Abs were paid consultants to the KIGS and KIMS Scientific Committee respectively.

\section{Funding}

The KIMS database is sponsored by Pfizer, Inc. 


\section{Acknowledgements}

The authors thank all the KIMS investigators and patients who consented to provide the data.

\section{References}

1 May JA, Krieger MD, Bowen I \& Geffner ME. Craniopharyngioma in childhood. Advances in Pediatrics 200653 183-209. (doi:10.1016/j.yapd.2006.04.013)

2 Gautier A, Godbout A, Grosheny C, Tejedor I, Coudert M, Courtillot C, Jublanc C, De Kerdanet M, Poirier JY, Riffaud L et al. Markers of recurrence and long-term morbidity in craniopharyngioma: a systematic analysis of 171 patients. Journal of Clinical Endocrinology and Metabolism $2012 \quad 97$ 1258-1267. (doi:10.1210/jc.2011-2817)

3 Pereira AM, Schmid EM, Schutte PJ, Voormolen JH, Biermasz NR, van Thiel SW, Corssmit EP, Smit JW, Roelfsema F \& Romijn JA. High prevalence of long-term cardiovascular, neurological and psychosocial morbidity after treatment for craniopharyngioma. Clinical Endocrinology 200562 197-204. (doi:10.1111/j.1365-2265. 2004.02196.x)

4 Sherlock M, Ayuk J, Tomlinson JW, Toogood AA, AragonAlonso A, Sheppard MC, Bates AS \& Stewart PM. Mortality in patients with pituitary disease. Endocrine Reviews 201031 301342. (doi:10.1210/er.2009-0033)

5 Bulow B, Attewell R, Hagmar L, Malmstrom P, Nordstrom CH \& Erfurth EM. Postoperative prognosis in craniopharyngioma with respect to cardiovascular mortality, survival, and tumor recurrence. Journal of Clinical Endocrinology and Metabolism $1998 \mathbf{8 3}$ 3897-3904. (doi:10.1210/jc.83.11.3897)

6 Tomlinson JW, Holden N, Hills RK, Wheatley K, Clayton RN, Bates AS, Sheppard MC \& Stewart PM. Association between premature mortality and hypopituitarism. West Midlands Prospective Hypopituitary Study Group. Lancet 2001357 425-431. (doi:10.1016/S0140-6736(00)04006-X)

7 Elowe-Gruau E, Beltrand J, Brauner R, Pinto G, Samara-Boustani D, Thalassinos C, Busiah K, Laborde K, Boddaert N, Zerah M et al. Childhood craniopharyngioma: hypothalamus-sparing surgery decreases the risk of obesity. Journal of Clinical Endocrinology and Metabolism 2013 98 2376-2382. (doi:10.1210/jc.2012-3928)

8 Pietila S, Makipernaa A, Sievanen H, Koivisto AM, Wigren T \& Lenko HL. Obesity and metabolic changes are common in young childhood brain tumor survivors. Pediatric Blood E Cancer 2009 52 853-859. (doi:10.1002/pbc.21936)

9 Srinivasan S, Ogle GD, Garnett SP, Briody JN, Lee JW \& Cowell CT. Features of the metabolic syndrome after childhood craniopharyngioma. Journal of Clinical Endocrinology and Metabolism 200489 81-86. (doi:10.1210/jc.2003-030442)

10 Simpson H, Savine R, Sonksen P, Bengtsson BA, Carlsson L, Christiansen JS, Clemmons D, Cohen P, Hintz R, Ho K et al. Growth hormone replacement therapy for adults: into the new millennium. Growth Hormone \& IGF Research 200212 1-33. (doi:10.1054/ghir.2001.0263)

11 Gutierrez LP, Koltowska-Haggstrom M, Jonsson PJ, Mattsson AF, Svensson D, Westberg B \& Luger A. Registries as a tool in evidencebased medicine: example of KIMS (Pfizer International Metabolic Database). Pharmacoepidemiology and Drug Safety 2008 17 90-102. (doi:10.1002/pds.1510)

12 Cook DM, Yuen KC, Biller BM, Kemp SF \& Vance ML. American Association of Clinical Endocrinologists medical guidelines for clinical practice for growth hormone use in growth hormonedeficient adults and transition patients - 2009 update. Endocrine Practice 200915 (Suppl 2) 1-29. (doi:10.4158/EP.15.S2.1)

13 Molitch ME, Clemmons DR, Malozowski S, Merriam GR \& Vance ML. Evaluation and treatment of adult growth hormone deficiency: an Endocrine Society clinical practice guideline. Journal of Clinical Endocrinology and Metabolism 201196 1587-1609. (doi:10.1210/jc.2011-0179)
14 Underwood LE \& Murphy MG. Radioimmunoassay of the somatomedins/insulin-like growth factors. In Radioimmunoassay in Basic and Clinical Pharmacology (198724), pp 561-574. Eds C Patrano \& BA Peskar, Berlin: Springer-Verlag, 1987.

15 Brabant G, Krogh Rasmussen A, Biller BM, Buchfelder M, FeldtRasmussen U, Forssmann K, Jonsson B, Koltowska-Haggstrom M, Maiter D, Saller B et al. Clinical implications of residual growth hormone $(\mathrm{GH})$ response to provocative testing in adults with severe GH deficiency. Journal of Clinical Endocrinology and Metabolism 200792 2604-2609. (doi:10.1210/jc.2007-0153)

16 Brabant G, von zur Muhlen A, Wuster C, Ranke MB, Kratzsch J, Kiess W, Ketelslegers JM, Wilhelmsen L, Hulthen L, Saller B et al. Serum insulin-like growth factor I reference values for an automated chemiluminescence immunoassay system: results from a multicenter study. Hormone Research 200360 53-60. (doi:10.1159/000071871)

17 Fossati P \& Prencipe L. Serum triglycerides determined colorimetrically with an enzyme that produces hydrogen peroxide. Clinical Chemistry $1982 \mathbf{2 8}$ 2077-2080.

18 Lopes-Virella MF, Stone P, Ellis S \& Colwell JA. Cholesterol determination in high-density lipoproteins separated by three different methods. Clinical Chemistry 197723 882-884.

19 McKenna SP, Doward LC, Alonso J, Kohlmann T, Niero M, Prieto L \& Wiren L. The QoL-AGHDA: an instrument for the assessment of quality of life in adults with growth hormone deficiency. Quality of Life Research 19998 373-383. (doi:10.1023/A:100 8987922774)

20 Koltowska-Haggstrom M, Mattsson AF \& Shalet SM. Assessment of quality of life in adult patients with GH deficiency: KIMS contribution to clinical practice and pharmacoeconomic evaluations. European Journal of Endocrinology 2009161 (Suppl 1) S51-S64. (doi:10.1530/EJE-09-0266)

21 Poretti A, Grotzer MA, Ribi K, Schonle E \& Boltshauser E. Outcome of craniopharyngioma in children: long-term complications and quality of life. Developmental Medicine and Child Neurology 200446 220-229. (doi:10.1111/j.1469-8749.2004.tb00476.x)

22 Balkau B \& Charles MA. Comment on the provisional report from the WHO consultation. European Group for the Study of Insulin Resistance (EGIR). Diabetic Medicine 199916 442-443. (doi:10.1046/j.1464-5491.1999.00059.x)

23 Caldarelli M, Massimi L, Tamburrini G, Cappa M \& Di Rocco C. Long-term results of the surgical treatment of craniopharyngioma: the experience at the Policlinico Gemelli, Catholic University, Rome. Child's Nervous System 200521 747-757. (doi:10.1007/ s00381-005-1186-5)

24 Merchant TE, Kiehna EN, Sanford RA, Mulhern RK, Thompson SJ, Wilson MW, Lustig RH \& Kun LE. Craniopharyngioma: the St. Jude Children's Research Hospital experience 1984-2001. International Journal of Radiation Oncology, Biology, Physics 200253 533-542. (doi:10.1016/S0360-3016(02)02799-2)

25 Fusco A, Miele L, D’Uonnolo A, Forgione A, Riccardi L, Cefalo C, Barini A, Bianchi A, Giampietro A, Cimino V et al. Non-alcoholic fatty liver disease is associated with increased GHBP and reduced GH/IGF-I levels. Clinical Endocrinology $2012 \quad 77$ 531-536. (doi:10.1111/j.1365-2265.2011.04291.x)

26 Leung KC. Johannsson G, Leong GM \& Ho KK. Estrogen regulation of growth hormone action. Endocrine Reviews 2004 25 693-721. (doi:10.1210/er.2003-0035)

27 Chrisoulidou A, Beshyah SA, Rutherford O, Spinks TJ, Mayet J, Kyd P, Anyaoku V, Haida A, Ariff B, Murphy M et al. Effects of 7 years of growth hormone replacement therapy in hypopituitary adults. Journal of Clinical Endocrinology and Metabolism $2000 \mathbf{8 5}$ 3762-3769. (doi:10.1210/jc.85.10.3762)

28 Hoffman AR, Strasburger CJ, Zagar A, Blum WF, Kehely A \& Hartman ML. Efficacy and tolerability of an individualized dosing regimen for adult growth hormone replacement therapy in comparison with fixed body weight-based dosing. Journal of Clinical Endocrinology and Metabolism 200489 3224-3233. (doi:10.1210/jc.2003-032082)

29 Verhelst J, Kendall-Taylor P, Erfurth EM, Price DA, Geffner M, Koltowska-Haggstrom M, Jonsson PJ, Wilton P \& Abs R. Baseline 
characteristics and response to 2 years of growth hormone $(\mathrm{GH})$ replacement of hypopituitary patients with $\mathrm{GH}$ deficiency due to adult-onset craniopharyngioma in comparison with patients with nonfunctioning pituitary adenoma: data from KIMS (Pfizer International Metabolic Database). Journal of Clinical Endocrinology and Metabolism 2005904636 -4643. (doi:10.1210/jc.2005-0185)

30 Christ ER, Cummings MH, Jackson N, Stolinski M, Lumb PJ Wierzbicki AS, Sonksen PH, Russell-Jones DL \& Umpleby AM. Effects of growth hormone $(\mathrm{GH})$ replacement therapy on low-density lipoprotein apolipoprotein B100 kinetics in adult patients with GH deficiency: a stable isotope study. Journal of Clinical Endocrinology and Metabolism $2004 \mathbf{8 9} 1801-1807$. (doi:10.1210/jc.2003-031474)

31 Trivin C, Busiah K, Mahlaoui N, Recasens C, Souberbielle JC, Zerah M, Sainte-Rose C \& Brauner R. Childhood craniopharyngioma: greater hypothalamic involvement before surgery is associated with higher homeostasis model insulin resistance index. BMC Pediatrics 2009 9 24. (doi:10.1186/1471-2431-9-24)
32 Cohen M, Guger S \& Hamilton J. Long term sequelae of pediatric craniopharyngioma - literature review and 20 years of experience. Frontiers in Endocrinology 20112 81. (doi:10.3389/fendo. 2011.00081)

33 Yuen K, Cook D, Ong K, Chatelain P, Fryklund L, Gluckman P, Ranke MB, Rosenfeld R \& Dunger D. The metabolic effects of shortterm administration of physiological versus high doses of $\mathrm{GH}$ therapy in GH deficient adults. Clinical Endocrinology $2002 \mathbf{5 7}$ 333-341. (doi:10.1046/j.1365-2265.2002.01601.x)

34 Crowley RK, Hamnvik OP, O'Sullivan EP, Behan LA, Smith D, Agha A \& Thompson CJ. Morbidity and mortality in patients with craniopharyngioma after surgery. Clinical Endocrinology 201073 516-521.

Received 3 April 2013

Revised version received 7 July 2013

Accepted 29 July 2013 